\title{
A giant Pseudomonas phage from Poland
}

\author{
Zuzanna Drulis-Kawa $\cdot$ Tomasz Olszak • \\ Katarzyna Danis • Grazyna Majkowska-Skrobek • \\ Hans-W. Ackermann
}

Received: 26 May 2013/Accepted: 31 July 2013/Published online: 26 September 2013

(C) The Author(s) 2013. This article is published with open access at Springerlink.com

\begin{abstract}
A novel giant phage of the family Myoviridae is described. Pseudomonas phage PA5oct was isolated from a sewage sample from an irrigated field near Wroclaw, Poland. The virion morphology indicates that PA5oct differs from known giant phages. The phage has a head of about $131 \mathrm{~nm}$ in diameter and a tail of $136 \times 19 \mathrm{~nm}$. Phage PA5oct contains a genome of approximately $375 \mathrm{kbp}$ and differs in size from any tailed phages known. PA5oct was further characterized by determination of its latent period and burst size and its sensitivity to heating, chloroform, and $\mathrm{pH}$.
\end{abstract}

Keywords Bacteriophage $\cdot$ DNA size $\cdot$ Giant .

Myoviridae $\cdot$ Pseudomonas

$\begin{array}{ll}\text { Abbreviations } \\ \text { PFU } & \text { Plaque-forming unit } \\ \mathrm{g} & \text { Unit of gravity } \\ \text { TMV } & \text { Tobacco mosaic virus }\end{array}$

Z. Drulis-Kawa $(\bowtie) \cdot$ T. Olszak · K. Danis ·

G. Majkowska-Skrobek

Institute of Genetics and Microbiology, University of Wroclaw, Przybyszewskiego 63/77, 51-148 Wroclaw, Poland

e-mail: zuzanna.drulis-kawa@microb.uni.wroc.pl

H.-W. Ackermann

Department of Microbiology-Infectiology and Immunology,

Medical School, Laval University, Quebec, 1050, avenue de la Médecine, Quebec G1X 4C6, Canada

\section{Introduction}

Nearly 6,000 tailed bacteriophages have be examined in the electron microscope, making them the largest viral group known. They contain double-stranded DNA and constitute the order Caudovirales, which is divided into three families: the Myoviridae, with long contractile tails (about $25 \%$ of observations, e.g., coliphage T4), the Siphoviridae, with long noncontractile tails $(57 \%$, represented by coliphage $\lambda$ ), and the Podoviridae, with short tails (14\%, exemplified by coliphage T7) [1]. All three groups vary enormously in size, DNA content, physicochemical properties, and structural elements such as collars, tail fibers and spikes. Clearly, tailed phages are highly evolved and enormously diversified. Myovirus bacteriophages, particularly of enterobacteria, Bacillus, and Pseudomonas tend to be larger than sipho- and podoviruses. Inordinately large phages with DNA contents of over $200 \mathrm{kbp}$ have been called "jumbo bacteriophages" [2, 3]. They have been found in bacteria as diverse as E. coli, vibrios, Sphingomonas [2], pseudomonads [2, 4], Ralstonia [3, 5], and Yersinia [6, 7]. A few, found in Aeromonas and Vibrio, with DNA contents of 233-244 kbp, have typical T4 morphology and slightly elongated heads [8]. These "jumbo phages" consist of a heterogeneous mixture of medium-sized phages and truly giant viruses that dwarf anything in the viral world except the recently discovered mimiviruses of the protozoon, Acanthamoeba [9] and some phycodnaviruses [10]. The very largest bacteriophage known, Bacillus megaterium phage $\mathrm{G}$, has a head of 160 $\mathrm{nm}$ in diameter and a tail of $455 \mathrm{~nm}$ in length (Table 1). We present here a Pseudomonas aeruginosa myovirus that is larger than any Pseudomonas phages known, is the thirdlargest bacterial virus after Bacillus phage G, and possibly represents a novel genus of bacterial viruses. 
Table 1 A gallery of the largest phages in the literature

\begin{tabular}{|c|c|c|c|c|c|c|}
\hline \multirow[t]{2}{*}{ Host } & \multirow[t]{2}{*}{ Phage } & \multicolumn{2}{|c|}{ Dimensions [nm] } & \multirow[t]{2}{*}{ DNA [kbp] } & \multirow[t]{2}{*}{ Calibration } & \multirow[t]{2}{*}{ References } \\
\hline & & Head & Tail length & & & \\
\hline Alicyclobacillus acidoterrestris & $\mathrm{P} 10$ & 152 & 240 & & catalase & {$[18]$} \\
\hline Bacillus megaterium & G & 160 & 453 & 497 & catalase & $\begin{array}{l}{[2,8,26]} \\
\text { GenBank JN638751.1 }\end{array}$ \\
\hline Caulobacter crescentus & $\begin{array}{l}\varphi \mathrm{Cr} 26 \\
\varphi \mathrm{Cr} 24\end{array}$ & $\begin{array}{l}160 \\
140\end{array}$ & $\begin{array}{l}140 \\
140\end{array}$ & & diffraction grating replica & {$[24]$} \\
\hline Cronobacter sakazakii & GAP32 & 115 & 118 & 358 & T4 tails & Abbasifar (conference report) \\
\hline Gluconobacter oxydans & GW6210 & 170 & 136 & $\sim 275$ & TMV & [25] \\
\hline \multirow[t]{2}{*}{ Escherichia coli } & $121 Q$ & 116 & 115 & 341 & catalase & {$[2,23]$} \\
\hline & PBECO4 & 132 & 125 & 348 & none & [19] \\
\hline Klebsiella sp. & RaK2 & 123 & 128 & 346 & catalase, T4 tails & {$[20,21]$} \\
\hline Proteus vulgaris & 121 & 150 & 150 & & none & {$[22]$} \\
\hline Pseudomonas aeruginosa & PA5oct & 131 & 136 & 375 & T4 tails & this work \\
\hline Ralstonia solancearum & $\varphi \mathrm{RSL} 1$ & $123-150$ & $105-138$ & 231 & $\lambda$ phage & {$[3,5]$} \\
\hline Unknown & $X$ & 156 & 119 & & catalase & [16] \\
\hline
\end{tabular}

kbp, kilobase pair; nm, nanometer; TMV, tobacco mosaic virus

\section{Materials and methods}

Phage isolation

The Pseudomonas aeruginosa PAO1 (ATCC 15692) strain, purchased from the American Type Culture Collection (ATCC), was used as a host for phage propagation. A water sample taken from irrigated fields was centrifuged at $15,000 \mathrm{~g}$ for $15 \mathrm{~min}$, and the supernatant was filtered through a 0.22- $\mu \mathrm{m}$ Millex-GP filter (Merck Millipore, Darmstadt, Germany, SLGP033RS). One $\mathrm{ml}$ of filtered water sample and $0.5 \mathrm{ml}$ of a broth culture of $P$. aeruginosa PAO1 strain, grown overnight in TSB, were added to $10 \mathrm{ml}$ of TSB and incubated at $37{ }^{\circ} \mathrm{C}$ for $18 \mathrm{~h}$. The suspension was then centrifuged again and filtered through a $0.22-\mu \mathrm{m}$ Millex-GP filter. This procedure was repeated three times to eliminate any bactericidal activity of chemicals possibly present in the water samples. The presence of bacteriophage and the titre in the filtrate were determined by the appearance of plaques on the bacterial lawn using the double-agar layer technique [11]. Phage PA5oct was deposited in the Félix d'Herelle collection at Laval University under the accession number HER 483.

\section{Electron microscopy}

A filtered high-titer phage lysate was centrifuged at $25,000 \times \mathrm{g}$ for $60 \mathrm{~min}$, using an Beckman (Palo Alto, CA) J2-21 centrifuge and a JA19.1 fixed-angle rotor. The pellet was washed twice in ammonium acetate $(0.1 \mathrm{M}, \mathrm{pH} 7.0)$ under the same conditions. Phages were deposited on copper grids with carbon-coated Formvar films and stained for $10 \mathrm{~s}$ with uranyl acetate $(2 \%, \mathrm{pH} 4.5)$ or phosphotungstate ( $2 \%, \mathrm{pH} 7)$. Excess liquid was blotted off and phages were examined under a Philips EM 300 electron microscope. The magnification was calibrated using T4 phage tails as a standard [12].

Pulsed-field gel electrophoresis (PFGE) analysis

A $10-\mathrm{ml}$ sample of filtered phage lysate with a titer of $10^{8}$ $\mathrm{PFU} / \mathrm{ml}$ was concentrated by centrifugation $(15,000 \mathrm{~g}$ for 25 min) using a Sigma 3-30 K Spincontrol Comfort centrifuge with a 19776 rotor (Sigma Zentrifugen $\mathrm{GmbH}$, Germany) in a solution of $1 \mathrm{M} \mathrm{NaCl}$ and $10 \%$ PEG 6,000 (Acros Organics, Geel, Belgium, 192280010). The sedimented precipitate was suspended in $1 \mathrm{ml}$ of TE buffer (1 mM EDTA, $10 \mathrm{mM}$ Tris, pH 8.0). Sample plugs were prepared by mixing equal volumes of concentrated phage suspension with melted and cooled $\left(40{ }^{\circ} \mathrm{C}\right)$ low-meltingpoint agarose (BioShop ${ }^{\circledR}$ Canada Inc., Burlington, ON, AGA101). Prepared blocks were placed in lysis buffer (50 mM Tris, $50 \mathrm{mM}$ EDTA, $1 \%$ SDS) and digested for $2 \mathrm{~h}$ with proteinase $\mathrm{K}$ at $54{ }^{\circ} \mathrm{C}$. After digestion, plugs were rinsed four times with TE buffer. DNA samples were separated on a $1 \%$ agarose gel using a Bio-Rad (Hercules, CA, U.S.A.) CHEF-DR III system $\left(16.5 \mathrm{~h}, 6 \mathrm{~V} / \mathrm{cm}, 12{ }^{\circ} \mathrm{C}\right.$, switch time $1-50$, angle $\left.120^{\circ}\right)$. Yeast Chromosome PFG Marker (New England Biolabs, Ipswich, MA, U.S.A., N0345S) was used as a size marker. 
One-step growth

One-step growth was determined according to the method of Pajunen et al. [13], with modifications. An equal volume of a mid-exponential bacterial culture in TSB was mixed with phage suspension $\left(2.5 \times 10^{6} \mathrm{PFU} / \mathrm{ml}\right)$ to obtain a multiplicity of infection of 0.01 . Phages were allowed to adsorb for $8 \mathrm{~min}$ at $37{ }^{\circ} \mathrm{C}$, after which time the mixture was diluted to $10^{-4}$. Triplicate samples were taken at 5 -min intervals for titration.

Sensitivity of PA5oct to heat, chloroform, and $\mathrm{pH}$

The thermal resistance of PA5oct at various temperatures $\left(40,50,60,70\right.$, and $\left.80{ }^{\circ} \mathrm{C}\right)$ was determined by incubating the phage $\left(9.7 \times 10^{8} \mathrm{PFU} / \mathrm{ml}\right)$ at the respective temperature for 5, 15, 30, 45 and $60 \mathrm{~min}$ at $\mathrm{pH} 7.4$ in TSB. Bacteriophage titers were assessed by the double agar layer technique [11]. Chloroform sensitivity was estimated by incubating equal volumes of phage suspension $\left(1.9 \times 10^{9}\right.$ $\mathrm{PFU} / \mathrm{ml}$ ) and chloroform for $1 \mathrm{~h}$ at room temperature and $4{ }^{\circ} \mathrm{C}$ with intermittent shaking, followed by titration. The $\mathrm{pH}$ sensitivity was studied by inoculating a volume of $100 \mu \mathrm{l}$ of bacteriophage suspension $\left(9.7 \times 10^{9} \mathrm{PFU} / \mathrm{ml}\right)$ into $900 \mu \mathrm{l}$ of TSB medium of $\mathrm{pH} 3-11$. Phages were titrated after incubation for $1 \mathrm{~h}$ and $24 \mathrm{~h}$ at room temperature.

\section{Results}

Phage PA5oct, alternatively named vB_PaeM_PA5oct in a new nomenclature system [14], was isolated from sewage collected from irrigated fields in a wastewater treatment plant near Wroclaw, Poland. Phage titers were $10^{8}-10^{9} \mathrm{PFU} /$ $\mathrm{ml}$ with 1 -mm-wide clear plaques on soft agar $(0.7 \%)$. Electron microscopy showed extremely large, mostly intact myoviruses and very large amounts of cell debris (Fig. 1). Heads measured $131 \mathrm{~nm}$ between opposite apices (60 measurements) and were icosahedral as shown by the simultaneous observation of capsids with hexagonal and pentagonal outlines. Unlike Pseudomonas phage $\varphi$ KZ [15], no inclusion bodies were observed in empty phage heads. Tails measured $136 \times 19 \mathrm{~nm}$ in the extended state and consisted of a neck of $10 \mathrm{~nm}$, a sheath with about 25 transverse striations, and an indistinct base plate of $33 \times 7-10 \mathrm{~nm}$ with short fibers of $30 \times 2 \mathrm{~nm}$. No collar was observed, but many phages carried amorphous material at the neck. Contracted tail sheaths measured $50 \times 30 \mathrm{~nm}$ and were separated from the base plate by a space of about $2 \mathrm{~nm}$. As determined by PFGE, the genome size of PA5oct was about $375 \mathrm{kbp}$ (Fig. 2). The genome of PA5oct is going to be sequenced.

One-step growth experiments indicated a latent period of 40 min and a burst size of about $30-40$ phage particles per infected bacterial cell. Phage PA5oct was stable at a temperature of $40-60{ }^{\circ} \mathrm{C}$, where no reduction of $\mathrm{PFU} / \mathrm{ml}$ was observed over a period of $60 \mathrm{~min}$. More than $60 \%$ of phages remained infective after a 15 -min incubation at $70{ }^{\circ} \mathrm{C}$, while only $13 \%$ phages were alive after a 60 -min incubation at this temperature. By contrast, after $5 \mathrm{~min}$ of incubation at $80{ }^{\circ} \mathrm{C}, 98 \%$ of phages lost their activity. No reduction in infectivity was observed after treatment with chloroform at a concentration of $50 \%$ for $1 \mathrm{~h}$ at room temperature or at $4{ }^{\circ} \mathrm{C}$. Phage particles were relatively stable within a $\mathrm{pH}$ range of 5-11 after incubation at room temperature (almost $90 \%$ of phages were alive), with the exception of $24 \mathrm{~h}$ of incubation at $\mathrm{pH} 11.0$, where a $50 \%$ reduction in phage activity was observed. When exposed to pH 3.0 for $60 \mathrm{~min}$, phage titers dropped by $10 \%$ and after $24 \mathrm{~h}$ of incubation, $<20 \%$ of phages were still alive.

\section{Discussion}

PA5oct is larger than the largest Pseudomonas phages known, namely the $\varphi \mathrm{KZ}$ phage group of $P$. aeruginosa, whose members are characterized by head diameters of about $124 \mathrm{~nm}$ and a tail length of $184 \mathrm{~nm}[4,15]$. It is also larger than phage Lu11 of $P$. putida, which has nearly the same dimensions, but has three or more curly fibers attached to its tail [4]. Phage PA5oct is truly unique among Pseudomonas phages, of which about 550 have been studied by electron microscopy [1].

The largest myovirus known, and also the largest phage in terms of capsid size and DNA content, is Bacillus megaterium phage G. It has a head of $160 \mathrm{~nm}$ in diameter and contains a DNA of 497,513 bp [GenBank accession number JN638751.1]. The next-largest phages with seemingly secure dimensions are phages $\mathrm{P} 10$ of Alicyclobacillus acidoterrestris, PA5oct, GAP32 of Cronobacter sakazakii, coliphage 121Q, and an entity called the X particle that was observed in the fluid of crushed silkworm larvae and never propagated [16]. Fig. 1 shows PA5oct, the X particle [16], and Bdellovibrio bacteriovorus phage $\varphi 1402$, which is the smallest known autonomous myovirus and which has a genome of only 23,931 bp [17]. P10 was obtained from Germany for inclusion in the Félix d'Herelle collection at Laval University (www.phage.ulaval.ca) and was photographed [18], but it was lost for unknown reasons. Phage GAP32 is a member of an emerging group of large phages, which possibly represent a new genus [Abbasifar R, Kropinski AM, Sabour PM, Ackermann H-W, Lavigne R, Alanis Villa A, Nash JHE, Vandersteegen K, Griffiths MW. 2013. Supersize me: Cronobacter sakazakii phage GAP32. Proc Viruses of Microbes, Brussels, Belgium, July 16-20, 2012]. It comprises coliphage 121Q, phage PBECO4 of E. coli 157:H6, and perhaps Klebsiella phage 

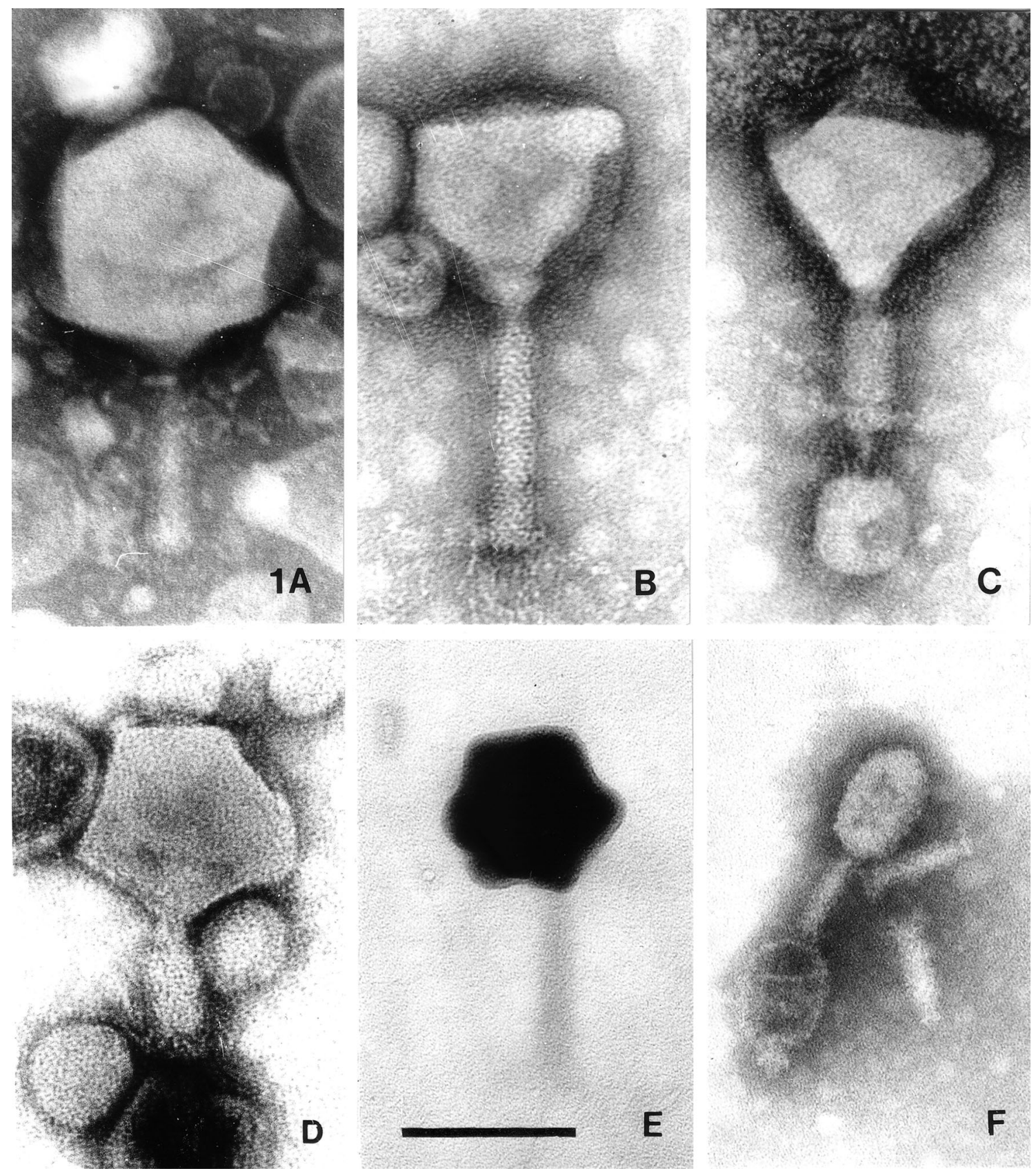

Fig. 1 Phage PA5oct and a giant and a very small myovirus for comparison. A the X particle with extended tail. Note its enormous head and relatively short tail [16]. B to $\mathbf{E}$ phage PA5oct. B normal phage with an extended tail; $\mathbf{C}$ chance observation of a phage with a contracted tail and base plate, adsorbed to small bacterial debris (the triangular aspect of the phage head is normal); D phage with a

RaK2 [19-21]. The members of this group are characterized by very large heads, relatively short tails, and limited genomic relationships with other phages. Most of these viruses were measured after calibration of magnification with catalase crystals (Table 1).

Although genome size determination and genome sequencing are now common techniques, some giant pentagonal head and a contracted tail; $\mathbf{E}$ phage with a positively stained head (such heads are always shrunken and should not be measured); F Bdellovibrio bacteriovorus phage $\varphi 1402$. The picture shows one intact phage, two isolated tails, and an empty head [17]. $\mathbf{A}$ and $\mathbf{F}$ phosphotungstate; $\mathbf{B}$ to $\mathbf{E}$, uranyl acetate. Final magnification, 297,000×; the bar indicates $100 \mathrm{~nm}$

phages, especially those reported in the 1970s or 1980s, were identified by electron microscopy only. The literature includes a series of phages with uncertain or dubious dimensions, obtained without or with questionable magnification controls. Proteus phage 121 was published as early as 1969, apparently without a control [22]. Indeed, H.-W.A. found a morphologically identical coliphage, 


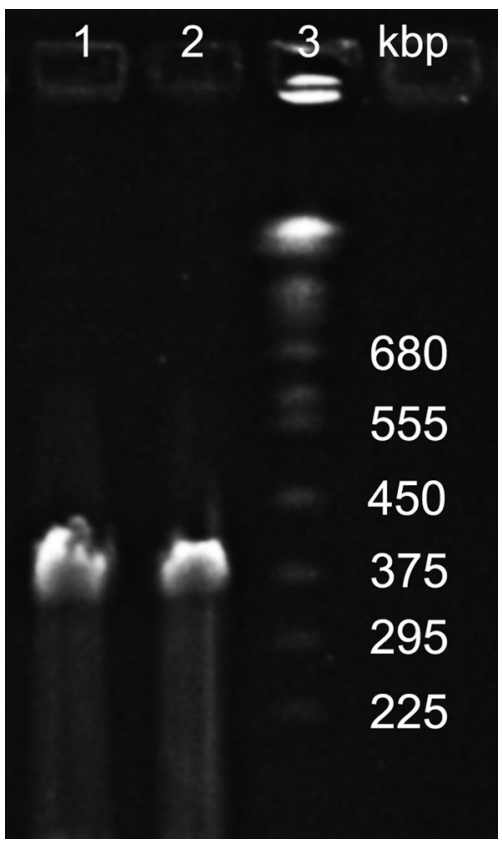

Fig. 2 PFGE analysis of PA5oct phage DNA (lanes 1 and 2); Yeast Chromosome PFG Marker (lane 3)

121Q, that appeared substantially smaller [23]. The size of Caulobacter phages $\varphi \mathrm{Cr} 24$ and $\varphi \mathrm{Cr} 26$ was determined by means of diffraction grating replicas, an internal standard that is good for low magnification (x30-40,000 only) and totally unsuitable for high magnification (x200-300,000) [24]. Gluconobacter phage GW6210 is certainly a giant virus, but it was measured by calibration with tobacco mosaic virus (TMV). The latter is fragile and disintegrates easily into small rods of variable length. This suggests that the Gluconobacter phage was measured after calibration with virus fragments [25]. Ralstonia phage $\varphi$ RSL1 was measured after calibration with phage $\lambda$ which has a flexible tail and appears intrinsically inappropriate as a size standard. The published micrographs of $\varphi$ RSL1 were unsatisfactory, but Yamada et al. later obtained excellent images and measured a head diameter of $125 \mathrm{~nm}$, which suggest that $\varphi$ RSL1 is related to the GAP32 group [personal communication, 5].

Size determination is one of the weakest points in viral electron microscopy. Even if the right test specimens are used, calibration of magnification is problematic. The adjustment of the electron microscope or photographic enlarger can be a difficult procedure and, if wrongly done, a source of errors. Beef liver catalase crystals are the only internal standard available for calibration at high magnification, but the crystals are fragile and disintegrate easily. Instead of catalase crystals, H.-W.A. has been using uranyl acetate-stained $\mathrm{T} 4$ phage tails for many years. When calibrated with catalase, they are $114 \mathrm{~nm}$ long, which equals
33-34 $\mathrm{mm}$ at a magnification of $\mathrm{x} 300,000$ [12]. T4 tails are stable for years, large enough to be measured with some certainty, and small enough to be numerous in a field. Other standards have also been used, e.g., TMV crystals, but they have not won acceptance. In conclusion, phage PA5oct appears to be the third-largest phage known, after Bacillus phage $\mathrm{G}$ and Alicyclobacillus phage P10.

Acknowledgements This study was supported by Polish National Science Centre Research Grant No. 2012/04/M/NZ6/00335. ZDK acknowledge project COST BM1003, "Microbial cell surface determinants of virulence as targets for new therapeutics in cystic fibrosis".

Conflict of interest The authors declare that they have no competing interests.

Open Access This article is distributed under the terms of the Creative Commons Attribution License which permits any use, distribution, and reproduction in any medium, provided the original author(s) and the source are credited.

\section{References}

1. Ackermann H-W, Prangishvili D (2012) Prokaryote viruses studied by electron microscopy. Arch Virol 157:1843-1849. doi:10.1007/s00705-012-1383-y1

2. Hendrix RW (2009) Jumbo bacteriophages. In: Van Etten JL, (ed.), Lesser known large dsDNA viruses. Curr Top Microbiol Immunol 328:229-240, Berlin, Springer

3. Yamada T, Satoh S, Ishikawa H, Fujiwara A, Takeru Kawasaki T, Fujie M, Ogata H (2009) A jumbo phage infecting the phytopathogen Ralstonia solanacearum defines a new lineage of the Myoviridae family Virology 398:135-137. doi:10.1016/j.virol. 2009.11.043

4. Krylov VN, Dela Cruz DM, Hertveldt K, Ackermann H-W (2007) " $\varphi$ KZ-like viruses", a proposed new genus of myovirus bacteriophages. Arch Virol. 152:1955-1959. doi:10.1007/ s00705-010-0783-0

5. Effantin G, Hamasaki R, Kawasaki T, Bacia M, Moriscot C, Weissenhorn W, Yamada T, Schoehn G (2013) Cryo-electron microscopy three-dimensional structure of the jumbo phage $\varphi$ RSL1 infecting the phytopathogen Ralstonia solanacearum. Structure 21:298-305. doi:10.1016/j.str.2012.12.017

6. Kiljunen S, Hakala K, Pinta E, Huttunen S, Pluta P, Gador A, Lonnberg H, Skurnik M (2005) Yersinophage $\varphi R 1-37$ is a tailed bacteriophage having a $270 \mathrm{~kb}$ DNA genome with thymidine replaced by deoxyuridine. Microbiology 151:4093-4102. doi:10. 1099/mic.0.28265-0

7. Skurnik M, Hyytiäinen HJ, Happonen LJ, Kiljunen S, Dattta N, Mattinen L, Williamson K, Kristo P, Szeliga M, Kalin-Mänttäri L, Ahola-Iivarinen E, Kalkkinen N, Butcher SJ (2012) Characterization of the genome, proteome, and structure of yersiniophage $\varphi$ R1-37. J Virol 86:12625-12642. doi:10.1128/JVI.0178312

8. Lavigne R, Darius P, Summer EJ, Seto D, Mahadevan P, Nilsson AS, Ackermann H-W, Kropinski AM (2009) Classification of Myoviridae bacteriophages using protein sequence similarity. BMC Microbiol 9: 224 doi:10.1186/1471-2180-9-224

9. La Scola B, Audic S, Robert C, Jungang L, de Lamballerie X, Drancourt M, Birtles R, Claverie JM, Raoult D (2003) A giant 
virus in amoebae Science 299 (5615) 20233; PMID 12663818; doi:10.1126/science.1081867

10. Dunigan DD, Fitzgerald LA, Van Etten JL (2006) Phycodnaviruses: a peek at genetic diversity. Virus Res 117:119-132

11. Adams MH (1959) Bacteriophages. Interscience Publishers, New York, $\mathrm{p} 27$

12. Ackermann HW (2009) Basic phage electron microscopy. In Bacteriophages: Methods and Protocols, Vol. 1, eds. A.M. Kropinski and M. Clokie. Ser. Methods in Molecular Biology, 501, 113-126. Humana Press, Totowa, NJ

13. Pajunen M, Kiljunen S, Skurnik M (2000) Bacteriophage $\varphi \mathrm{YeO} 3-12$, specific for Yersinia enterocolitica serotype O:3, is related to coliphages T3 and T7. J Bacteriol 182:5114-5120

14. Kropinski A, Prangishvili D, Lavigne R (2009) Position paper: the creation of a rational scheme for the nomenclature of viruses of Bacteria and Archaea. Environ Microbiol 11:2775-2777. doi:10.1111/j.1462-2920.2009.01970.x

15. Krylov VN, Smirnova TA, Minenkova IB, Plotnikova TG, Zhazikov IZh, Khrenova EA (1984) Pseudomonas bacteriophage $\varphi \mathrm{KZ}$ contains an inner body in its capsid. Can J Microbiol 30:758-762

16. Ackermann H-W, Auclair P, Basavarajappa S, Emadi Konjin HP, Savanurmath C (1994) Bacteriophages from Bombyx mori. Arch Virol 137:185-190

17. Ackermann H-W, Krisch HM, Comeau AM (2011) Morphology and genome sequence of phage $\varphi 1402$ : A dwarf myovirus of the predatory bacterium Bdellovibrio bacteriovorus. Bacteriophage 3:138-142. doi:10.4161/bact.1.3.15769

18. Ackermann H-W, Azizbekyan RR, Emadi Konjin HP, Lecadet M-M, Seldin L, Yu MX (1994) New Bacillus bacteriophage species Arch Virol 135:333-344
19. Kim MS, Hong SS, Park KS, Myung H (2013) Genomic analysis of bacteriophage PBECO4 infecting Escherichia coli 0157:H7 Arch Virol. pii:1007/SC00705-03-1718-3

20. Simoliunas E, Kaliniene L, Truncaite L, Klausa V, Zajanckauskaite A, Meskys R (2012) Genome of Klebsiella sp.infecting bacteriophage vB_KleM_RaK1 J Virol 86:5406. doi:10. 1128/JVI.00347-12

21. Simoliunas E, Kalienine L, Truncaite L, Zajanckauskaite A, Staniulis J, Meskys AR. (2013) Klebsiella phage vB_KleMRaK2-a giant singleton virus of the family Myoviridae PLoS One 8(4) e60717. doi:10.1371/journal.pone.0060717

22. Nacesco N, Constantinesco SP, Petrovici A (1969) Aspects électrono-optiques du phage convertisseur Proteus vulgaris 121. Arch Roum Pathol Exp Microbiol 28:838-848

23. Ackermann H-W, Nguyen T-M (1983) Sewage coliphages investigated by electron microscopy. Appl Environ Microbiol 45:1049-1059. doi:10.1016/j.watres.2005.06.010

24. Johnson RC, Wood NB, Ely B (1977) Isolation and characterization of bacteriophages for Caulobacter crescentus. J Gen Virol 37:323-335

25. Robakis NK, Palleroni NJ, Despreaux CW, Boublik M, Baker CA, Churn PJ, Claus GW (1985) Isolation and characterization of two phages for Gluconobacter oxydans. J Gen Microbiol 131:2467-2473. doi:10.1099/00221287-131-9-2467

26. Ageno M, Donelli G, Guglielmi F (1973) Structure and physicochemical properties of bacteriophage G II. The shape and symmetry of the capsid. Micron 4:376-403 